\title{
Europeanisation Beyond the Member States
}

\author{
by Frank Schimmelfennig
}

Europeanisation does not end at the external borders of the European Union. Through conditionality, socialisation, externalisation, and imitation, the EU generates external effects. The comparison of EU relations with "quasi-member states", candidate countries, the European neighbourhood, other OECD countries, and far-away regions shows that the mechanisms and conditions of Europeanisation vary significantly across contexts. In general, however, market power and supranational regulation are the most important conditions of effectiveness. In their absence, the EU's institutions can merely serve as an agency for socialisation and a model for imitation - albeit with a limited and superficial impact.

Europäisierung endet nicht an den Grenzen der Europäischen Union. Durch Konditionalität, Sozialisation, Externalisierung und Imitation nimmt die EU Einfluss auf das Regieren von Drittstaaten. Ein Vergleich der EU-Beziehungen mit den „Quasi-Mitgliedstaaten “, den Beitrittskandidaten, der Europäischen Nachbarschaft, den übrigen OECDLändern und entfernteren Regionen zeigt, dass der grenzüberschreitende Einfluss je nach Kontext stark variiert. Im Allgemeinen sind Marktmacht und supranationale Regulierung aber die wichtigsten Bedingungen der Europäisierung jenseits der EU. In Abwesenheit dieser Bedingungen kann die EU allenfalls als Sozialisationsagentur und Imitationsvorlage dienen-allerdings mit begrenzten und oberflächlichen Wirkungen.

\section{Introduction}

When speaking of "European governance" (notwithstanding the ambiguity of the term), we usually have in mind that the European Union (EU) provides rules and mechanisms to regulate the behaviour of public and private actors across a great variety of integrated policy areas. "Europeanisation" is then generally understood as the domestic impact of, and adaptation to, European governance in the EU's member states; or, in Claudio Radaelli's encompassing definition, the incorporation of "formal and informal rules, procedures, policy paradigms, styles, "ways of doing things', and shared beliefs and norms, which are first defined and con- 
solidated in the making of EU public policy and politics ... in the logic of domestic discourse, identities, political structures, and public policies."

Since the 1990s, however, EU scholars have begun to look beyond the formal borders of the EU and study the impact of European governance on external actors. This widening of the horizon was a result of three major developments in European integration. First, as a consequence of its Single Market Program and a series of enlargement rounds, the EU deepened and expanded its internal market. The size and attractiveness of this market accorded the EU considerable power to shape the economic and public policy rules of global governance and its trading partners. Second, the EU embarked on Eastern enlargement, which was not only bigger but also considerably more intrusive and transformative than previous enlargement rounds. It pursued the ambitious goal of ensuring that the accession countries would transpose the entire acquis communautaire - the body of EU law - ahead of joining the Union, and accession negotiations were mostly about planning and monitoring this Europeanisation process. Third, the EU has designed novel institutional arrangements for those countries that are either not willing to become members (the European Economic Area and the bilateral treaties with Switzerland) or not eligible for membership (the Barcelona process (since 1995) for the Mediterranean neighbours and the European Neighbourhood Policy (ENP, since 2003) for the Eastern European, Middle Eastern and Northern African neighbours). At their core, these institutional arrangements are directed at managing interdependence by aligning neighbouring countries with EU policies and rules, while avoiding formal membership.

In sum, the EU provides "external governance". It projects its model and rules of governance to the outside and, if successful, contributes to the Europeanisation of national and international governance beyond the borders of formal membership. ${ }^{2}$ This survey article will first discuss the contents of Europeanisation beyond the EU. Which are the "European" modes and rules of governance that the EU projects beyond its borders (Section II)? In addition, it will present different mechanisms of Europeanisation and the conditions under which these are likely to have an impact on outside actors (Section III). The article subsequently de-

1 Radaelli, C.: The Europeanization of Public Policy, in: Featherstone; K./Radaelli, C. (eds.): The Politics of Europeanization, Oxford, 2003, 27-56, 30.

2 Lavenex, S./Schimmelfennig, F.: EU Rules Beyond EU Borders: Theorizing External Governance in European Politics, in: Journal of European Public Policy 16/6, 2009, 791-812, 795. 
scribes diverse the modes and impacts of Europeanisation in diverse international settings (Section IV). Section V concludes.

In a nutshell, the argument seeks to go beyond the common characterisation of the EU as a "civilian" or "normative power" because these labels blur the distinction between goals, means, and impact and do not capture the cross-regional variation in mechanisms, conditions, and outcomes of Europeanisation. It argues that effective Europeanisation is the product of EU conditionality and the externalisation of EU rules under the conditions of EU market power and supranational, i.e. centralised and hierarchical, regulation.

\section{Model Europe: the meaning of Europeanisation beyond the EU}

What are the contents of "external governance"? What kind of "Europeanisation" does the EU pursue or produce beyond its borders? Most basically, we can start from the assumption of "domestic analogy". According to this assumption, polities prefer to have an international environment that resembles, or is at least compatible with, their domestic principles and procedures. The substantive goals - as well as instruments - of Europeanisation will thus mirror the principles of EU integration and governance. ${ }^{3}$ In other words, Europeanisation consists in "the external projection of internal solutions."

From a rational perspective, an international environment that mirrors the EU is in the best interest of EU political and economic actors. It is an environment that they are familiar with and know to use to their benefit - and one that reflects their own institutional and policy choices. This reduces adaptation and information costs and gives them a potential advantage over other actors. ${ }^{5}$ Other authors emphasise shared values and norms as well as established routines and templates of the EU as the source of external projection. Federica Bicchi, for instance, suggests that EU external policy can "be seen as unreflexive behaviour mirroring the deeply engrained belief that Europe's history is a lesson for everybody.",

3 Peters, D./Wagner, W.: Die Europäische Union in den internationalen Beziehungen, in: Holzinger, K. et al.: Die Europäische Union. Theorien und Analysekonzepte, Paderborn, 2005, 215-272, 215-216.

4 Lavenex, S.: EU External Governance in "Wider Europe", in: Journal of European Public Policy 11/4, 680-700, 695.

5 Peters, D./Wagner, W., op. cit., 216.

6 Bicchi, F.: "Our size fits all": Normative Power Europe and the Mediterranean, in: Journal of European Public Policy 13/2, 286-303, 287. 


\section{Beyond "civilian" or "normative power Europe"}

The debate on the essence of European governance or the European model is as multifaceted as it is inconclusive. The best-known sweeping categorisations of "external governance" describe the EU as a distinctive kind of "power" in the international system. In the early 1970s, François Duchêne introduced the label of "civilian power" to characterise the EU as a novel international actor that has overcome the anarchical self-help system of international politics internally. "Civilian power" - as opposed to "military power" - refers to both means and ends, to the use of civil instruments of governance rather than the use of force, and to civilising the international system by transforming it into a system of rulebased governance according to its own model. In another influential attempt to characterise the EU's special role in world affairs, Ian Manners invented the term "normative power". ${ }^{8}$ According to the "normative power" perspective, the EU's impact on the global system is ideational. It shapes global conceptions of what is "normal" based on its founding principles such as peace, liberty, democracy, human rights, and the rule of law - principles that were shaped in turn by the historical context of the EU's origin, its hybrid (international and supranational) character, and its political-legal constitution.

Despite their prominence in the discussion about the EU's role in the world, the two concepts of "civilian power" and "normative power" are problematic. First, they mix prescription and description; they relate to both what the EU currently is and what it ought to be. In addition, the two concepts are part of the EU's official self-image and self-portrayal, which is a noteworthy fact in itself that critical evaluation. Second, their multidimensionality as descriptions of means, ends, and impact makes the two concepts indeterminate. What if the EU promotes normative goals with civilian (economic) means as in political conditionality or inflicts economic sanctions on human rights violators? What if the EU pursues civilian ends with military means? The irresolvable debate on whether the EU ceased to be a civilian power when it acquired military capabilities, even though it used them for military operations with a civilising goal, is indicative of this indeterminacy. Finally, and most importantly, the EU's ends and means in global politics have changed over time and vary across countries and regions.

7 Duchêne, F.: Europe's Role in World Peace, in: Mayne, R. (ed.): Europe Tomorrow: Sixteen Europeans Look Ahead, London, 1972, 32-47.

8 Manners, I.: Normative Power Europe: a Contradiction in Terms?, in: Journal of Common Market Studies 40/2, 2002, 235-258. 
Such variation cannot be adequately described by uniform labels or attributed to the EU's "ontological quality".

Just as there is not a single mode of governance within the EU, "external governance" also varies across geographical and functional space. It is thus empirically more adequate to differentiate the contents as well as the mechanisms of Europeanisation and to analyse under which conditions they operate and are effective. As Karen Smith has rightly remarked in a recent research agenda article, "debates about whether the EU is or is not a civilian power, a normative power, a superpower, and so on, are not really leading us anywhere right now ... We should instead engage in a debate about what the EU does, why it does it, and with what effect, rather than about what it is." ${ }^{10}$ In an effort to disentangle the "EU power syndrome", I therefore distinguish ends, means, and mechanisms, and make impact (Europeanisation) an empirical question.

\section{Principles of European governance}

Regarding the ends, we can further distinguish general principles of governance and the governance of specific issues. For the EU as a regionally integrated system of liberal democracies, "European governance" is in essence defined by regionalism, supranational integration, multilateralism, transnational markets, the regulatory state, and democratic constitutionalism. According to the domestic analogy, Europeanisation then consists in the adoption of these principles beyond the EU.

First, the EU typifies regional integration. It proposes regional economic integration and the establishment of supranational organisations as the pathway to peace and welfare in other parts of the world. ${ }^{11}$ From its immediate neighbours in the Balkans to the distant regions of Sub-Saharan Africa, Asia, and Latin America, the EU has established forums and agreements with regional organisations and earmarked aid specifically for fostering regional cooperation and integration. At the global level, the EU seeks to reproduce its own model of "intensive multilat-

9 Manners, I., op. cit., 252.

10 Smith, K.: The European Union in the World: Future Research Agendas, in: Egan, M./Nugent, N./Paterson, William E. (eds.): Research Agendas in EU Studies. Stalking the Elephant, Basingstoke, 2010, 329-353, 343.

11 Bicchi, F., op. cit.; Farrell, M.: From EU Model to External Policy? Promoting Regional Integration in the Rest of the World, in Meunier, S./McNamara, K. (eds.): Making History. European Integration and Institutional Change at Fifty, Oxford, 2007, 299-315. 
eralism" ${ }^{12}$ by working within and strengthening multilateral international organisations. $^{13}$

Second, the EU stands for the creation and regulation of transnational markets. In a critical perspective, the EU has been described to propagate a "neoliberal" economic model, which reflects the EU's internal commitment to marketbuilding and economic liberalisation. ${ }^{14}$ Others point out, however, that the EU rather seeks to disseminate a multilaterally managed "regulatory framework for liberal markets" according to its own model. ${ }^{15}$ The EU is further seen to embody the "regulatory model" of policymaking, ${ }^{16}$ which it projects abroad and uses to spread its own rules beyond its borders.

Finally, the EU promotes constitutional norms such as human rights, the rule of law and democracy in its external relations. ${ }^{17}$ They mirror the constitutional principles of its member states and its accession criteria. Since the late 1980s and early 1990s, the EU has made the promotion of democracy and human rights a standard feature of its external relations across the globe. Since the mid-1990s, the EU has inserted a human rights clause (which envisages the suspension of cooperation in cases of severe human rights violations) in all general agreements with non-industrialised third countries, and it has mainstreamed the promotion of human rights and democracy into its external policies.

These general principles have attracted high attention in the literature on the EU's external action and its role in global governance. But everyday EU "external governance" and its impact on third countries is arguably much more shaped by the issue-specific regimes of the EU in a broad variety of public policies constituting the EU's acquis communautaire. They are too numerous to be listed here. Yet the basic assumption of the "external projection of internal solutions"

12 Wallace, W.: Europe After the Cold War: Interstate Order or Post-Sovereign Regional System?, in: Review of International Studies 25/2, 1999, 201-223.

13 Laatikainen, K./Smith, K.: Introduction - The European Union at the United Nations: Leader, Partner or Failure?, in: Laatikainen, K./Smith, K. (eds.): The European Union at the United Nations. Intersecting Multilateralisms, Basingstoke, 2006, 1-23.

14 See, e.g., Hurt, S.: Co-operation and coercion? The Cotonou Agreement between the European Union and ACP States and the End of the Lomé Convention, in: Third World Quarterly, 24/1, 2003, 161-176.

15 Grugel, J.: New Regionalism and Modes of Governance - Comparing US and EU Strategies in Latin America, in: European Journal of International Relations 10/4, 2004, 603-626, 616.

16 Majone, G.: Regulating Europe. London, 1996; Orbie, J.: A Civilian Power in the World? Instruments and Objectives in European Union External Policies, in: Orbie, J. (ed.): Europe's Global Role. Aldershot, 2008, 1-33.

17 Manners, I., op. cit., 240-241. 
holds for issue-specific governance as well. Not only does the EU transfer its specific policy rules beyond its borders. There is evidence that the modes of "external governance" also correspond to the modes of internal governance for the same issues. For instance, the EU promotes network governance externally for those policies - such as research policy - that are pursued via network governance in the EU, whereas hierarchical internal policies such as transport are also organised hierarchically in the EU's relations with neighbouring countries. ${ }^{18}$

In sum, the EU seeks to project its model of governance beyond its borders. This model consists in a combination of regional integration, a multilaterally regulated international market, and liberal democracy - together with a myriad of policy-specific rules based on its acquis communautaire. As subsequent sections will show, however, this model is projected with very different substantive emphases and in very different ways across the target regions and countries of "external governance".

\section{Mechanisms of Europeanisation}

How does Europeanisation beyond EU borders occur? What are the mechanisms and processes through which the EU disseminates its institutions and rules of governance in the wider international system? Several largely overlapping classifications of Europeanisation mechanisms have been suggested in the literature. ${ }^{19}$ I propose a simple two-by-two table ${ }^{20}$ that distinguishes direct from indirect mechanisms, and those that follow a rationalist logic of consequences from those that build on a logic of appropriateness (see Table 1).

18 Lavenex, S./Lehmkuhl, D./Wichmann, N.: Modes of External Governance: a Cross-National and CrossSectoral Comparison, in: Journal of European Public Policy, 16/6, 2009, 813-833.

19 Bauer, M./Knill, C./Pitschel, D.: Differential Europeanisation in Eastern Europe: The Impact of Diverse EU Regulatory Governance Patterns, in: Journal of European Integration, 29/4, 2007, 405-423; Diez, T./Stetter, S./Albert, M.: The European Union and Border Conflicts: The Transformative Power of Integration, in: International Organization 60/3, 2006, 563-593; Lavenex, S./Uçarer, E.: The External Dimension of Europeanization, in: Cooperation and Conflict, 39/4, 2004, 417-443; see also Schimmelfennig, F.: Europeanization Beyond Europe, in: Living Reviews in European Governance, 4/3, 2009, available at http://www.livingreviews.org/lreg-2009-3.

20 See Schimmelfennig, F./Sedelmeier, U.: Introduction: Conceptualizing the Europeanization of Central and Eastern Europe, in: Schimmelfennig, F./Sedelmeier, U. (eds.): The Europeanization of Central and Eastern Europe, Ithaca, 2005, 1-28. 
Table 1: Mechanisms and Conditions of Europeanisation

\begin{tabular}{l|c|c}
\hline $\begin{array}{l}\text { Logic of } \\
\text { consequences }\end{array}$ & Direct & Indirect \\
\hline $\begin{array}{c}\text { Conditionality } \\
\text { (size and credibility } \\
\text { of incentives, } \\
\text { costs of compliance) }\end{array}$ & $\begin{array}{c}\text { Externalisation } \\
\text { (market size, legalisation } \\
\text { and centralisation of rules) }\end{array}$ \\
\hline $\begin{array}{l}\text { Logic of } \\
\text { appropriateness }\end{array}$ & $\begin{array}{c}\text { Socialisation } \\
\text { ("noviceness" and uncertainty; }\end{array}$ \\
\hline
\end{tabular}

Direct mechanisms are those in which the EU takes a pro-active stance and intentionally seeks to disseminate its model and rules of governance beyond its borders. By contrast, indirect ones are those in which either non-EU actors have the active part or the mere presence of the EU generates unintended external effects. According to the logic of consequences, Europeanisation proceeds through the manipulation of incentives and the change of cost-benefit calculations in third countries. By contrast, according to the logic of appropriateness, Europeanisation is an effect of the perceived authority and legitimacy of the EU, its model of governance, or its norms and rules.

Conditionality is a direct mechanism of Europeanisation, which is based on the EU's manipulation of other actors' cost-benefit calculations. The EU seeks to disseminate its governance rules by setting them as conditions that external actors have to meet in order to obtain rewards and to avoid sanctions from the EU. The most relevant rewards are different types of agreements ranging from trade agreements to accession treaties and the provisions of market access and financial aid that come with them. Correspondingly, the EU's sanctions consist in suspending or terminating such agreements. Typically, however, the EU uses positive conditionality. Rather than sanctioning countries, it keeps them in the waiting room for an agreement until they meet the conditions. The effectiveness of this mechanism depends on the size of the EU's rewards and the credibility of its conditionality. Credibility results from superior bargaining power and a consistent application of conditionality, i.e. the EU needs to be less dependent on or interested in the agreement than its partner, and the partner needs to be certain 
that it will receive the rewards only when the conditions are met. ${ }^{21}$ In addition, domestic adaptation costs must not be higher than the international rewards because otherwise a rational target state of conditionality will not comply.

Externalisation works through the EU's indirect impact on the cost-benefit calculations of external actors. In contrast with conditionality, the EU does not proactively promote its model or rules of governance beyond its own borders. Yet its sheer "presence" 22 as a market and a regional system of governance produces (sometimes unintended or unanticipated) externalities. External actors adopt and follow EU rules because ignoring or violating them would generate net costs. Firms interested in participating in the EU market must follow the EU's rules. Countries whose economies are strongly interconnected with the EU make their internal rules compatible with those of the EU. In general, the effects of externalisation increase with the market size of the EU and the strength of its regulatory institutions. ${ }^{23}$ The larger the EU's share is in the foreign trade of a country, and the more binding and centralised the EU's rules are, the more this country will be subject to Europeanisation pressures.

Socialisation comprises all EU efforts to disseminate European governance by persuading outside actors of the ideas and norms behind them. This is a direct mechanism of Europeanisation based on the logic of appropriateness. Rather than directly manipulating or indirectly affecting the cost-benefit calculations of external actors, the EU teaches them the principles and rules of European governance. External actors adopt and comply with EU rules if they are convinced of their legitimacy and appropriateness and if they accept the authority of the EU. This is more likely to be the case if the external actors are in a novel and uncertain environment, identify with and aspire to belong to "Europe". A process characterised by deliberation and frequent as well as dense contacts between the EU and external actors is also thought to help. Finally, high resonance of EU governance with domestic traditions, norms, and practices provides favourable conditions for effective socialisation. ${ }^{24}$

21 Schimmelfennig, F./Sedelmeier, U., op. cit., 12-16.

22 Allen, D./Smith M.: Western Europe's Presence in the Contemporary International Arena, in: Review of International Studies 16/1, 1990, 19-39.

23 Bach, D./Newman, A.: The European Regulatory State and Global Public Policy: Micro-institutions, Macro-influence, in: Journal of European Public Policy 14/6, 2007, 827-846.

24 Checkel, J.: Why Comply? Social Learning and European Identity Change, in: International Organization 55/3, 2001, 553-588, pp. 562-563; see also Risse, T.: "Let's Argue!" Communicative Action in World Politics, in: International Organization 54/1, 2000, 1-39, 19. 
Imitation works similarly but without a pro-active role of the EU. Rather, the EU serves as a role model of governance, which outside actors emulate. Nonmember actors imitate the EU because they recognise EU rules and policies as appropriate solutions to their own problems. Again, novices in the international system and states in an uncertain environment are more likely to look for and emulate role models. They are more likely to select the EU as their model if they identify with the EU, are in close contact with the EU, and find EU governance to resonate with their prior beliefs and practices.

\section{The Scope of Europeanisation}

Europeanisation beyond the EU is patchy. The contents and mechanisms of Europeanisation vary across regions, countries, organisations, and policies. Most fundamentally, we can think of EU "external governance" as occurring in five concentric circles: the quasi-member states of Western Europe, the candidate countries for membership, the neighbourhood countries, the OECD world, and other world regions (see Table 2 ). ${ }^{25}$

Table 2: Concentric Circles of "External Governance" and Europeanisation

\begin{tabular}{l|c|c|c|c}
\hline $\begin{array}{l}\text { Quasi- } \\
\text { members }\end{array}$ & $\begin{array}{c}\text { Market } \\
\text { regulation }\end{array}$ & $\begin{array}{c}\text { Conditionality and } \\
\text { Externalisation }\end{array}$ & $\begin{array}{c}\text { Strong } \\
\text { dependence }\end{array}$ & $\begin{array}{c}\text { Strong, } \\
\text { partial }\end{array}$ \\
\hline $\begin{array}{l}\text { Candidate } \\
\text { countries }\end{array}$ & All & Conditionality & $\begin{array}{c}\text { Strong } \\
\text { dependence, } \\
\text { strong incentives }\end{array}$ & $\begin{array}{c}\text { Strong, } \\
\text { general }\end{array}$ \\
\hline $\begin{array}{l}\text { Neighborhood } \\
\text { countries }\end{array}$ & All & $\begin{array}{c}\text { Conditionality and } \\
\text { Socialisation }\end{array}$ & $\begin{array}{c}\text { Medium } \\
\text { dependence, } \\
\text { weak } \\
\text { incentives }\end{array}$ & $\begin{array}{c}\text { Medium, } \\
\text { partial }\end{array}$ \\
\hline $\begin{array}{l}\text { OECD } \\
\text { countries }\end{array}$ & Market & Externalisation & $\begin{array}{c}\text { Medium } \\
\text { interdependence }\end{array}$ & $\begin{array}{c}\text { Medium, } \\
\text { partial }\end{array}$ \\
\hline Other regions & Regionalism & $\begin{array}{c}\text { Imitation (and } \\
\text { Socialisation) }\end{array}$ & $\begin{array}{c}\text { Weak } \\
\text { interdependence }\end{array}$ & Weak \\
\hline
\end{tabular}

25 For reasons of space, I do not discuss the EU's relations with the developing countries of Africa, the Caribbean, and the Pacific region (ACP countries) in the framework of the Cotonou agreement. 


\section{The Quasi-member Countries}

In 1992, the EU concluded the European Economic Area (EEA) agreement with the countries of the European Free Trade Association. According to the agreement, the EEA countries (Iceland, Norway, and Liechtenstein) are formally obliged to adopt all EU legislation regarding the Single Market and several related policy fields as well as the case law of the European Court of Justice. A Surveillance Authority and the EFTA Court enforce EU rules in the EEA countries. The EEA countries also participate in the informal preparation of EU legislation that concerns them ("decision-shaping"), but in contrast to full members, they do not take part in the formal decision-making process. The EEA countries comply extremely well with their legal obligations - at the level of the most compliant member states - and, for all practical purposes, they can be regarded as "quasi-members" that are subject to the core of EU rules and governance in almost the same way as the member states.

By contrast, Switzerland has opted for the "bilateral way", which comprises a series of 16 interlinked policy-specific agreements with the EU. It envisages neither general decision-shaping nor automatic adoption of subsequent EU laws nor supranational monitoring and enforcement. Switzerland's far-reaching regulatory alignment with the EU rather results from coordination in bilateral committees and the unilateral adoption of EU law and EU-compatible adaptation of Swiss law. Although the bilateral arrangements allow Switzerland to formally preserve its sovereignty de jure and be more selective regarding "Europeanisation", its de facto alignment with EU rules is similar to that of the EEA countries. $^{26}$

Quasi-membership results from high economic interdependence with the EU but strong popular opposition to full membership. In Norway and Switzerland, formal EU accession as desired by the political and economic elites was blocked by negative popular referendums, which forced these countries to manage their intense market and policy relationships with the EU below the level of full supranational integration. At the same time, the strong asymmetry in market size and trade shares results in the far-reaching formal or informal adoption of highly legalised EU rules by the quasi-members. The basic mechanism behind the Europeanisation of the quasi-members is a highly institutionalised form of conditionality (granting equal market access in return for rule adoption) tending to-

26 Lavenex, S./Lehmkuhl, D. (eds.): Switzerland's Flexible Integration in the EU (Special Issue), in: Schweizerische Zeitschrift für Politikwissenschaft 15/4, 2009. 
ward externalisation in the case of Switzerland. Quasi-membership is sustained by the independent economic success of these countries - e.g. Norway's oil wealth. As the case of Iceland after the financial crisis of 2008 shows, the demand for membership increases when autonomous economic success is threatened or has failed. ${ }^{27}$

\section{The Candidate Countries}

The EU's relations with the candidates for membership are another case of deep Europeanisation beyond the formal borders of the EU. Ahead of starting membership negotiations with prospective new members, the EU focuses on the general principles of European governance, in particular the political criteria of freedom, democracy, the rule of law, and respect for human rights stipulated by the Treaty on European Union as the main criteria of eligibility for membership (Art. 49 TEU).

By contrast, during the accession negotiations the focus is on the issue-specific rules of European governance. The concept of "negotiations", however, suggests an openness that does not exist in the accession process. The substantive outcome of the negotiations is largely pre-determined: the applicants' adoption of the entire body of EU legislation and policies codified in the acquis communautaire. Accession negotiations then mainly consist in a process of rule transfer, "screening" and "reporting", in which the EU explains the acquis to the applicants, assesses their deficits, and monitors their progress in transposing EU law. The only true negotiations concern the possibility and length of "transition periods" during which the application of EU rules is suspended after accession.

The mechanism of the Europeanisation of candidate countries is predominantly conditionality. The EU's main activities consist in setting conditions for membership, monitoring candidates' progress in compliance, and granting or withholding the reward accordingly. The conditions for effective conditionality are generally favourable in EU-candidate country relations. Membership is the biggest reward the EU can offer to outsider countries. It gives them full and equal access to the internal market, the funds, the decision-making institutions, and the legal remedies of the most important economic and political organisation of the continent. In addition, the credibility of conditionality is generally high as well.

27 For a general argument along these lines, see Mattli, W.: The Logic of Regional Integration. Europe and Beyond, Cambridge, 1999. 
Usually, interdependence is highly asymmetrical in favour of the EU because the candidates' economies are of lesser importance to the EU than the EU market is to the candidates. The EU can thus afford to set strict conditions and to say "no". With a few exceptions (regarding, for instance, Cyprus and Turkey), the EU has also been rather consistent in applying its conditions, and candidates could expect to be admitted after fulfilling them. In the case of the Central and Eastern European countries, we can observe that their adoption of EU policy rules was selective and patchy during the early transition period and often followed domestic traditions or the rules of other international organisations. Once they had been offered a credible membership perspective, however, their public policies converged toward the EU model - except for those issues in which the EU has only weak competencies or indeterminate rules. ${ }^{28}$

The domestic political costs of compliance for the target governments are the main obstacle to effective conditionality in the candidate countries. Regarding liberal-democratic political conditionality, these costs have proven prohibitive for regimes whose preservation of power depends on undemocratic institutions and practices. Even a credible and attractive offer of EU membership cannot turn the benefit calculations of such regimes positive. Moreover, national identity issues (such as minority rights and ethnic conflict in the Baltic countries and the Balkans) have also proven difficult to overcome. ${ }^{29}$ As concerns acquis conditionality, domestic interest groups adversely affected by European integration are the major problem. In the case of Eastern enlargement, however, they have largely been absent or proven to be relatively weak.

\section{The Neighborhood Countries}

The European Neighbourhood Policy (ENP) was introduced by the EU during the time of its "big bang" enlargement of 2004 in order to expand and strengthen its relationship with neighbouring countries that would not be considered as candidates for membership - at least for the foreseeable future. Originally conceived to encompass the enlarged EU's Eastern European neighbours, it was

28 Schimmelfennig, F./Sedelmeier, U.: Conclusions: The Impact of the EU on the Accession Countries, in: Schimmelfennig, F./Sedelmeier, U. (eds.): The Europeanization of Central and Eastern Europe, Ithaca, 2005, 210-228, 215-220.

29 Schimmelfennig, F./Engert, S./Knobel, H.: International Socialization in Europe. Regional Organizations, Political Conditionality, and Democratic Change, Basingstoke, 2006. See also Freyburg, T./Richter, S.: National Identity Matters: the Limited Impact of EU Political Conditionality in the Western Balkans, in: Journal of European Public Policy 17/2, 263-281. 
later extended to the Middle Eastern and North African (MENA) partner countries of the Euro-Mediterranean Partnership ("Barcelona Process") and further to the Southern Caucasus. It excludes Russia, however, which insisted on pursuing a separate track of cooperation with the EU.

In principle, the ENP is based on the same encompassing notion of Europeanisation as accession policy. "Everything but institutions" was the promise of Commission President Romano Prodi, when the ENP idea was launched, that is, full participation of the neighbouring countries in material European governance if not in formal decision-making. In practice, however, the alignment has been unequal and patchy. Whereas accession obliges prospective members to adopt the entire acquis, and the old members to grant the new ones equal rights and entitlements, the ENP allows for flexibility that both sides can use to avoid costly obligations. Rather than being uniformly based on the EU acquis, the Action Plans at the core of ENP programming are negotiated and monitored bilaterally between the EU and its partners - according to the principle of "joint ownership".

The ENP also appears to copy the EU's accession conditionality. "Differentiation" is a fundamental principle. The ENP strategy documents tie both participation in the ENP as such and the intensity and level of cooperation to the ENP partners' adherence to liberal values and norms. Moreover, the EU uses planning, reporting and assistance procedures similar to those for candidate countries. The conditions of effective impact, however, are clearly weaker than in the case of the candidate countries. First, the most attractive "carrot" - EU membership is not on offer. The major incentives designed to induce Europeanisation in ENP countries are a liberalised access of goods and persons to the EU. Second, conditionality is inconsistent. Comparisons of ENP Action Plans show the absence of a coherent democracy promotion policy and the overriding importance of the EU's and the partner countries geostrategic and political interests. Finally, the domestic costs of liberalisation and democratisation are prohibitive in the mostly authoritarian regimes of the neighbourhood. As a result, democratic conditionality proves ineffective in the ENP context. In contrast to the candidate countries, the EU has not been able to help induce or consolidate democracy in the neighbourhood. ${ }^{30}$

30 Maier, S./Schimmelfennig, F.: Shared Values: Democracy and Human Rights, in: Weber, K./Smith, M./Baun, M. (eds.): Governing Europe's Neighbourhood. Partners or Periphery?, Manchester, 2007, 3957, 45-48. 
The EU's acquis conditionality in the neighbourhood has also suffered from weaknesses because the credibility of the market access incentive has been undermined by protectionist interest groups in the EU, the exclusion of sectors such as agriculture in which the ENP partners have a competitive edge, and fears of crime and uncontrolled immigration into the EU. ${ }^{31}$ In addition, the EU does not enjoy the same uncontested bargaining power as in its relationship with candidates for membership. This is particularly true for the energy-exporting countries of the region. Moreover, the EU competes with other powerful providers of "external governance", namely Russia. As a result, the EU only has a chance to export its own rules to the Neighbourhood if the target countries are dependent on the EU and more dependent on the EU than on other actors. ${ }^{32}$ Alternatively, "self-conditionality" appears to work. Countries that would like to become members - such as Ukraine, Moldova, or Georgia - behave as if they were subject to accession conditionality, adopt EU rules in order to signal their readiness to join, and seek to persuade the EU to consider them as candidates. ${ }^{33}$

Given the weak conditions for effective conditionality, many authors suggest that - despite the appearances of conditionality - the ENP is based de facto on a socialisation mechanism of Europeanisation. In this view, EU rules promoted in the context of ENP negotiations and policy networks may serve as a reference point for longer-term domestic political processes. ${ }^{34}$ It is questionable, however, whether the domestic conditions in the ENP countries are on the whole conducive to socialisation-driven change. That may be the case in the self-socialisation countries but identification with the EU community and resonance of EU rules is weak in most of the neighbourhood region. Recent studies find abundant evidence of transgovernmental networks engaged in extending EU governance to the neighbourhood. However, they also come to the conclusion that the operation and effectiveness of these networks is hampered by incompatible administrative

31 Weber, K./Smith, M./Baun, M. (eds.): Governing Europe's Neighbourhood. Partners or Periphery?, Manchester, 2006.

32 Dimitrova, A./Dragneva, R.: Constraining External Governance: Interdependence with Russia and the CIS as Limits to the EU's Rule Transfer in the Ukraine, in: Journal of European Public Policy 16/6, 2009, 853-872.

33 Verdun, A./Chira, G.: From Neighbourhood to Membership: Moldova's Persuasion Strategy Towards the EU, in: Southeast European and Black Sea Studies, 8/4, 2008, 431-444.

34 Freyburg, T./Lavenex, S./Schimmelfennig, F./Skripka, T./Wetzel, A.: EU Promotion of Democratic Governance in the Neighbourhood, in: Journal of European Public Policy, 16/6, 2009, 916-934; Sasse, G.: The European Neighbourhood Policy: Conditionality Revisited for the EU's Eastern Neighbours, in: Europe-Asia Studies, 60/2, 2008, 295-316. 
structures, cultures, expertise and lack of trust. ${ }^{35}$ In addition, EU norms, which have entered the legislation of some neighbouring countries, face severe obstacles to effective application. ${ }^{36}$

\section{The OECD world}

The quasi-member, candidate and neighbourhood countries are the domains of direct Europeanisation. Here, the EU pro-actively promotes its modes and rules of governance as part of an overarching strategy of regulatory alignment and common policies. Direct mechanisms of Europeanisation are much less in evidence beyond the neighbourhood. There, we find two typical contexts of indirect mechanisms of Europeanisation: the externalisation of EU governance through economic interdependence and competition in the highly industrialised OECD world, and the imitation of EU governance in other regions.

Governance by externalisation is typical for the export of EU rules in its relations with the democratic, market-oriented, and highly industrialised OECD countries. Here, the EU has neither the goal nor the means to embark on a wholesale export of the EU acquis. The larger OECD region is much less dependent on the Single Market than the neighbouring countries and lies beyond the zone of stability that the EU attempts to create in its surroundings. Enlargement is not even potentially on the agenda. The EU deals with the other OECD countries, above all the US, either bilaterally or in the context of global organisations such as the UN or the WTO.

For obvious reasons, the promotion of democracy and human rights is not an issue in EU relations with OECD countries. The human rights clause is therefore absent in agreements with countries in this group. EU rule export mostly concerns issue-specific rules related to its internal market. Case studies converge on the finding that EU impact is a function of both the size of the EU market (and its relevance for outsiders) and the strength of EU regulation. ${ }^{37}$ Whereas market size can be understood as a necessary condition of EU rule export because it creates an interest of market actors to get access to the EU market and their will-

35 Lavenex, S./Wichmann, N.: The External Governance of EU Internal Security, in: Journal of European Integration 33/1, 2009, 83-102.

36 Freyburg, $T$. et al., op. cit.

37 See, e.g., Bach, D./Newman, A., op. cit.; Princen, S.: Exporting Regulatory Standards: The Cases of Trapping and Data Protection, in: Knodt, M./Princen, S. (eds.): Understanding the European Union's External Relations, London, 2003. 
ingness to adopt EU rules, it is not sufficient alone if the EU's rules and their administration are weak, fragmented, and incoherent. Rather, the EU's impact depends on the EU regulatory state and increases with the supranationalisation of EU governance. The more legally binding and centrally administered EU rules are, the more the EU can transform latent market power into manifest political clout. The highly centralised competition policy with its extraterritorial impact on mergers and acquisitions and its multi-million Euro fines imposed on non-EU firms provides the most visible evidence for this relationship. Although initially set up to liberalise and strengthen the internal market, the regulatory powers of the EU also increasingly provide it with the means to shape international standards.

Studies of multilateral negotiations have come to the conclusion that both size and institutions matter. The EU's sheer size as a market, a provider of development aid, a polluter, etc., as well as the number of participants and votes it can muster in global negotiations give it considerable power resources. ${ }^{38}$ Whether and how the EU can convert these resources into power over outcomes, however, depends on institutions. One issue is whether or not the EU has exclusive competence in a policy area. As a rule, exclusive competence increases EU impact. Where it does not exist, it can be partially compensated by homogeneous preferences or informal coordination leading to a united stand of its member states. This has, for instance, been the case in global environmental policy. ${ }^{39}$ As Sophie Meunier shows for transatlantic trade negotiations, however, it also matters how exactly the EU's exclusive competence is designed. Whereas "unanimity voting strengthens the hand of the EU negotiators to resist demands for policy changes", it "weakens their ability to advocate changes". 40

\section{Other regions and regionalisms}

The indirect mechanism of imitation is best seen in the impact that the EU model has had on regional institution-building and economic integration in other parts of the world. The EU has not directly encouraged or induced the establishment of

38 Bretherton, C./Vogler, J.: The European Union as a Global Actor. London, 2006.; Orbie, J., op. cit.

39 Bretherton, C./Vogler, J., op. cit., 89-99; Damro, C.: EU-UN Environmental Relations: Shared Competence and Effective Multilateralism, in: Laatikainen, K./Smith, K. (eds.): The European Union at the United Nations. Intersecting Multilateralisms, Basingstoke, 2006, 175-192.

40 Meunier, S.: Trading Voices. The European Union in International Commercial Negotiations, Princeton, $2005,3$. 
major regional organisations such as the Andean Community and Mercosur in Latin America, ASEAN in Southeast Asia, or the African Union. Nor have these organisations and their reforms been a response to critical interdependence with the EU. But all of them have emulated EU institutions and policies. In the meantime, the EU has established institutionalised relationships, funds cooperation programs, and maintains a political dialogue with these regional organisations so that an element of socialisation is involved alongside imitation.

The uncertainty of the emulators and the legitimacy of the EU appear to be the main conditions for the imitation of EU institutions. Embracing the apparently successful EU model is perceived as a way to overcome crises of multilateral cooperation and integration in the regions. For instance, the Andean Pact was founded in 1969 as a response to the deficiencies of the Latin American Free Trade Association. To correct for its failures, the founders of the Pact leapfrogged towards the Community model of supranational integration including, among other features, majority voting, legal integration with a Court and the direct applicability and supremacy of supranational law, and - later on - a directly elected Andean Parliament. ${ }^{41}$ Similarly, ASEAN reacted to its shortcomings in dealing with the financial crisis of 1997 and related problems by questioning its decidedly non-European "ASEAN Way" of informal, consensual intergovernmental consultation and cooperation and of eschewing supranational economic integration. In the aftermath of this crisis, ASEAN policy-makers perceived the need for stronger formalisation and institutionalisation as well as more economic integration and started a process that eventually led to the adoption of a charter in 2005. In this process, the EU served as a source of inspiration for the constitutional structure as well as the project of a single market. ${ }^{42}$

As described by the notion of "decoupling" in the neo-institutionalist sociology of organisations, ${ }^{43}$ the emulated formal structures as responses to crisis and uncertainty were, however, either never truly implemented or co-existed with practices reflecting "old habits". The first option is most clearly seen in the Andean

41 Malamud, A./De Sousa, L.: Regional Parliaments in Europe and Latin America: Between Empowerment and Irrelevance, in: Ribeiro Hoffmann, A./Van der Vleuten, A. (eds.): Closing or Widening the Gap? Legitimacy and Democracy in Regional Integration Organizations, Aldershot, 2007, 85-102, 93-94.

42 Hwee, Y.: EU-ASEAN Relations and Policy-Learning, in: Balme, R./Bridges, B. (eds.): Europe-Asia Relations. Building Multilateralisms, Basingstoke, 2008, 83-102, 91-92; Börzel, T./Risse, T., op. cit., 13-15.

43 Meyer, J./Rowan, B.: Institutionalized Organizations: Formal Structures as Myth and Ceremony, in: American Journal of Sociology 83/2, 1977, 340-363. 
Community, whereas the second seems typical for the tendency of the member states of ASEAN to retain the practices of sovereignty, informality, and intergovernmentalism. ${ }^{44}$ At any rate, mimicry in formal appearance and emulation of actual practice need to be distinguished. In particular, the EU remains unique with regard to supranational integration, i.e. the pooling and delegation of sovereignty. For this reason, many institutions that bear the same name in other regional organisations - Commission, Council, Court, Committee of Permanent Representatives, or Parliament - perform different functions. The most striking example of decoupling is the African Union. Whereas the former Organisation of African Unity (OAU) not only adopted the EU's name but also its supranational institutions and policy programs (such as the monetary union), its practices could not be more different from the EU's. Decoupling can actually lead to a conscious decision to discard the EU model: as a response to the failures of the Andean Pact to implement its supranational institutions, the more recently established Mercosur abandoned the institutional model of the EU altogether and opted for an intergovernmental structure.

\section{Conclusions}

The EU has become a major player in global politics. Its "external governance" consists in exporting its internal rules and modes of governing to non-member countries and other international organisations, thereby contributing to the process of Europeanisation beyond the EU's borders. This article has sought to demonstrate that the "civilian" or "normative power" concept that continues to frame discussions of the EU's external relations is too unspecific to capture the various ways in which the EU exercises "external governance" - and its varying effectiveness. By contrast, it has tried to show how the mechanisms and conditions of Europeanisation vary across "concentric circles" of EU external relations.

At first sight, geography seems to matter strongly. The further we move away from the EU, the more indirect and weaker its impact becomes. Its direct neighbours (the quasi-member states and candidates for membership) experience the most direct and strongest Europeanisation, whereas the more distant OECD world or far away regions are only subject to indirect, patchy or weak Europeanisation. But geography is an imperfect match. It does not explain the irregular Europeanisation we find in the quasi-member states or the OECD world nor the

44 Hwee, Y., op. cit., 97-98. 
fact that rather distant countries like the US may be subject to stronger Europeanisation effects than closer ones like Algeria or Belarus.

The most important conditions cutting across the concentric circles of Europeanisation are market share and supranational regulation. Relevant market interactions and the material, economic incentives that come with them generate the need for external actors to adapt to the rules of European governance. But only to the extent that there is a clearly defined European rule - and one that is centrally decided and hierarchically enforced - can the EU speak with the necessary unity and authority to the outside world. ${ }^{45}$ Therefore, Europeanisation beyond the EU is likely to be strengthened as the EU's market power vis-à-vis third countries increases and as the relevant markets are supranationally regulated by the EU.

The strong impact that the EU has in the quasi-member and candidate countries is predicated upon the high and asymmetric interdependence with these countries, the substantial incentives of membership or full market access, and the hierarchical organisation of the accession process as well as the EEA. The difference between quasi-members and candidates can also generally be explained by the degree of dependence on the EU or the sustainability of economic autonomy. Relationships with the neighbourhood and the rest of the OECD world (e.g. the USA) are characterised by weaker and more symmetrical interdependence, weaker incentives, and a non-hierarchical institutional setting. Whereas the EU cannot impose its entire model in these relationships, it can still have a Europeanising impact with regard to specific governance rules where the conditions of critical market size and supranational regulation are present. Where these are absent, however, the EU's institutions can merely serve as a model for imitation or a socialisation agency.

As a corollary of the relevance of market power and hierarchy, the instrumental mechanisms, conditionality and externalisation, generate the strongest Europeanisation effects. Socialisation (in the case of neighbourhood countries) and imitation (in the case of far-away regions) generate only a weak or superficial independent impact. This does not entail, however, that the conditions linked to these mechanisms are completely unimportant. As the quasi-member states' resistance to membership and the problems of ethnic identity in the Balkans show, identity is a background condition for conditionality to succeed. Strong national, ethnic, or anti-European identities inhibit full integration even where 
asymmetric interdependence and market forces would suggest a closer relationship with the EU.

Effectiveness follows the same pattern when it comes to the contents of Europeanisation. The EU is most widely effective in disseminating policy rules connected with its internal market. Because imitation processes only create Potemkin villages, the EU's model of regional integration is really only extended through conditionality-based accession. And it is only in this context that the EU has been successful in assisting the consolidation of democracy.

In this article, I have attempted to go beyond the widespread tendency to describe the EU's external action in terms of civilian power, normative power (or some other adjective plus power) and to propose an analysis based on "external governance". The results, however, also shed light on the "power debate": they corroborate the civilian power image and cast doubt on the EU as a normative power. In general, the effective projection of EU governance beyond its borders depends on market power and supranational regulation rather than its normative socialisation capacity. Whenever the EU's promotion of norms is not backed up by the power of its regulated market, it hardly qualifies as a power at all. 